\title{
Cell suspensions from collagenase digestion of bone marrow trephine biopsy specimens
}

\author{
C J ADES, G A ABLETT, R J COLlins, I H BUNCE Department of Pathology, Royal Brisbane \\ Hospital, Brisbane, Australia
}

SUMMARY A technique for the extraction of cells from bone marrow trephine core biopsy specimens using collagenase digestion was assessed in 39 cases ( 33 diagnostic and six normal). Diagnostically useful numbers of cells were extracted from all marrows. Morphological assessment of cytocentrifuge preparations of these cells gave a correct diagnosis in $23(60 \%)$ of cases compared with $27(70 \%)$ for the corresponding aspirated marrow smears. Phenotypic analysis using flow cytometry showed persistence of a range of surface membrane antigens following collagenase digestion. Increased autofluorescence was a problem in some cases.

Cytochemistry, bone marrow culture, and cytogenetic analysis could also be carried out on these cells. It is concluded that this technique has useful diagnostic applications in cases of dry taps.

Dry bone marrow taps may occur in many haematological disorders. These include the densely cell packed marrow of acute leukaemia and some malignant lymphomas, the fibrotic marrow of myeloproliferative disorders and some lymphoproliferative disorders such as hairy cell leukaemia, and the hypocellular marrow of aplastic anaemia. When this occurs diagnosis is impaired as marrow aspirate smears are not available for cell morphology and cytochemistry. Furthermore, karyotyping, bone marrow culture, and immunological phenotyping techniques using cell suspensions cannot be done.

In these circumstances attempts to assess cell morphology by "roll imprints" are made but cell numbers and quality are poor. Alternatively, plastic embedded ultra thin histological section of bone marrow trephine biopsy specimens may be used, ' but this technique is difficult, labour intensive, and not available in every laboratory. Frozen section immunohistochemistry has been advocated for immunological phenotying of marrow in cases of dry taps, ${ }^{2}$ but this technique is also demanding and so not widely used.

We present and assess a simple alternative technique for use in cases of dry taps in which cell suspensions suitable for morphological assessment, cytogenetics and immunological phenotyping are prepared by collagenase digestion of trephine bone marrow core biopsy specimens.

Accepted for publication 3 November 1988

\section{Material and methods}

Thirty nine adult marrows were sampled over nine months. These included six normal marrows (disease free staging marrows) and 33 diagnostic marrows. Final diagnoses are listed in table 1.

An 11 gauge Jamshidi trephine biopsy needle was used to take unilateral or bilateral core biopsy specimens from the iliac crest. Bone marrow cores were divided transversely with a scalpel under sterile conditions. The sample for digestion was placed in $3 \mathrm{ml}$ of Iscove's modified Dulbeccos's medium (Gibco) containing $100 \mathrm{U}$ of preservative free heparin (IMDM + HEP) and the remainder fixed in formalin for histological analysis. Roll imprints were made before fixation in cases of dry taps.

Marrow smears were made directly and some aspirated marrow diluted in $3 \mathrm{ml}$ (IMDM + HEP) for further investigation. In all cases of a dry tap aspirates were attempted from multiple sites.

The trephine biopsy specimens were cleared of adherent clots using a scalpel, measured, then gently washed by replacing the medium twice using IMDM $+10 \%$ fetal calf serum. Collagenase (type II, Sigma No C-6885) in IMDM $+10 \%$ fetal calf serum was added to a final volume of $3 \mathrm{ml}$ and a final concentration of $0 \cdot 1 \%$. The trephine biopsy specimen was aspirated by applying a pasteur pipette directly to the core biopsy specimen. It was then incubated at $37^{\circ} \mathrm{C}$ with $5 \%$ carbon dioxide, $5 \%$ oxygen, and $90 \%$ nitrogen. A final aspiration was used to release the cells from the marrow trabeculae and to disperse the 
Table 1 Comparison of diagnoses by morphological assessment of three different marrow preparations

\begin{tabular}{|c|c|c|c|c|c|c|c|c|c|c|c|}
\hline \multirow[b]{2}{*}{$\begin{array}{l}\text { Diagnostic } \\
\text { groups }\end{array}$} & \multirow[b]{2}{*}{ No } & \multirow[b]{2}{*}{$\begin{array}{l}\text { Dry } \\
\text { tap }\end{array}$} & \multicolumn{3}{|c|}{ Aspirated marrow smears } & \multicolumn{3}{|c|}{ Roll imprints } & \multicolumn{3}{|c|}{ Marrow digest cytospins } \\
\hline & & & Correct & Incorrect & $\begin{array}{l}\text { Non- } \\
\text { diagnostic }\end{array}$ & Correct & Incorrect & $\begin{array}{l}\text { Non- } \\
\text { diagnostic }\end{array}$ & Correct & Incorrect & $\begin{array}{l}\text { Non- } \\
\text { diagnostic }\end{array}$ \\
\hline Acute leukaemia & 8 & 2 & 6 & & & 1 & & & 8 & & \\
\hline $\begin{array}{r}\text { (CMML, RA) } \\
\text { Chronic myeloid }\end{array}$ & 2 & & 2 & & & & & & 1 & & 1 \\
\hline $\begin{array}{l}\text { leukaemia } \\
\text { Myeloproliferative }\end{array}$ & 1 & & 1 & & & & & & & 1 & \\
\hline disorders & 3 & 1 & 2 & & & & & & 2 & 1 & \\
\hline Malignant lymphoma & 8 & 3 & 1 & 4 & & 1 & 4 & 1 & 5 & 2 & 1 \\
\hline Plasma cell dyscrasia & 3 & 1 & 2 & & & & & $i$ & 3 & & \\
\hline $\begin{array}{l}\text { Hairy cell leukaemia } \\
\text { Chronic lymphocytic }\end{array}$ & 2 & 1 & 1 & & & & 1 & & 2 & & \\
\hline leukaemia & 1 & & 1 & & & & & & & 1 & \\
\hline Secondary carcinoma & 1 & & 1 & & & & & & 1 & & \\
\hline Anaemia or cytopaenia & 3 & 1 & 1 & 1 & & & & & & & 3 \\
\hline Megaloblastic anaemia & 1 & & 1 & & & & & & 1 & & \\
\hline Normal aspirates & 6 & & 2 & & & & 1 & & & & 3 \\
\hline Total No $(\%)$ & 39 & $\begin{array}{l}9 / 39 \\
(23)\end{array}$ & $\begin{array}{l}21 / 30 \\
(70)\end{array}$ & $\begin{array}{l}7 / 30 \\
(23)\end{array}$ & $\begin{array}{l}2 / 30 \\
(7)\end{array}$ & $\begin{array}{l}2 / 10 \\
(20)\end{array}$ & $\begin{array}{l}6 / 10 \\
(60)\end{array}$ & $\begin{array}{l}2 / 10 \\
(20)\end{array}$ & $\begin{array}{l}23 / 39 \\
(60)\end{array}$ & $\begin{array}{l}8 / 39 \\
(20)\end{array}$ & $\begin{array}{l}8 / 39 \\
(20)\end{array}$ \\
\hline
\end{tabular}

released clumps. The cells were washed twice in IMDM and suspended in $1 \mathrm{ml}$ of IMDM $+10 \%$ fetal calf serum for electronic counting (Coulter Counter model ZF).

Cytocentrifuge preparations were made using $10^{5}$ to $2 \times 10^{5}$ cells per slide at $250 \mathrm{rpm}$ for five minutes. These slides were used for cell morphology, cytochemistry, and, as required, for in situ immune markers. The remaining cells were used for flow cytometric analysis and in some cases for cytogenetic analysis or clonogenic assays.

To further test the effects of collagenase on certain membrane markers cell culture and cell recovery, washed aspirate samples from the "normal" group and peripheral blood lymphocytes and mechanically dispersed spleen cells were used. Each sample was divided into equal aliquots. One aliquot was incubated with $0 \cdot 1 \%$ collagenase in IMDM $+10 \%$ fetal calf serum in the incubator for two hours or overnight and the other portion was analysed immediately. Cells exposed to collagenase were then washed twice and suspended in IMDM $+10 \%$ fetal calf serum, analysed, and results compared with those for untreated cells.

Surface membrane antigens were detected by an indirect immunofluorescence technique using various monoclonal antibodies: Leu4 (CD3), Leu3 (CD4), Leu2 (CD8), CoT11 (CD2), M3 (CD14), MY9 (CD33), HLe-1 (CD45), HLA-Dr, Leu 1 (CD5) and HPCA-1 (CD34) (Becton Dickinson, California, USA); B1 (CD20), B4 (CD19), and J5 (CD10) (Coulter Clone, Hialea, Florida); FMC 7, FMC 10 (CD15), FMC 16 (Australian Monoclonal Development, Australia); and mouse IgG and IgM (Becton Dickinson) as negative controls. Surface membrane immunoglobulin (SmIg) was detected by using directly labelled fluorescein isothiocyanate (FITC) $\mathrm{F}(\mathrm{ab})_{2}$ goat anti-human immunoglobulin (Tago, California, USA).

For membrane antigens $10^{6}$ cells in $50 \mu \mathrm{l}$ were incubated with $20 \mu \mathrm{l}$ of antibody (all antisera used were previously titred for optimal activity) at $4^{\circ} \mathrm{C}$ for 30 minutes, washed once in phosphate buffered saline containing $0.1 \%$ sodium azide (PBS), and then incubated with $20 \mu \mathrm{l}$ of optimally diluted FITC conjugated $F(a b)_{2}$ goat anti-mouse Ig (Tago, USA) for 30 minutes at $4^{\circ} \mathrm{C}$. The cells were washed in PBS and resuspended to $150 \mu$ in PBS before being analysed. SmIg was detected by incubating $10^{6}$ cells with appropriately diluted antibody at $4^{\circ} \mathrm{C}$ for 30 minutes, washing twice in PBS, and resuspending to $150 \mu \mathrm{l}$ with PBS.

For DNA analysis $10^{6}$ mononuclear cells in $20 \mu$ of $0 \cdot 1 \mathrm{M} \mathrm{PBS}, \mathrm{pH} 7 \cdot 2$, were stained at room temperature with $50 \mu \mathrm{l}$ of a solution of propidium iodide (propidium iodide $5 \mathrm{mg}$, RNAase $100 \mathrm{mg}$, Triton $\mathrm{X}-100200 \mu \mathrm{l}, 0 \cdot 1 \mathrm{M}$ PBS, pH 7.2, $20 \mathrm{ml}$ ) immediately before analysis. Immunofluorescence was measured using an EPICS 741 flow cytometer (Coulter Electronics, Florida, USA).

Karyotypic studies were done on 48 hour unstimulated cultures with trypsin Giemsa banding.

\section{Results}

\section{CELL RECOVERY}

Examination with a dissecting microscope indicated that cellular extraction was complete within two hours for all the normal marrows. Some marrows with noticeable fibrosis took longer to digest completely 


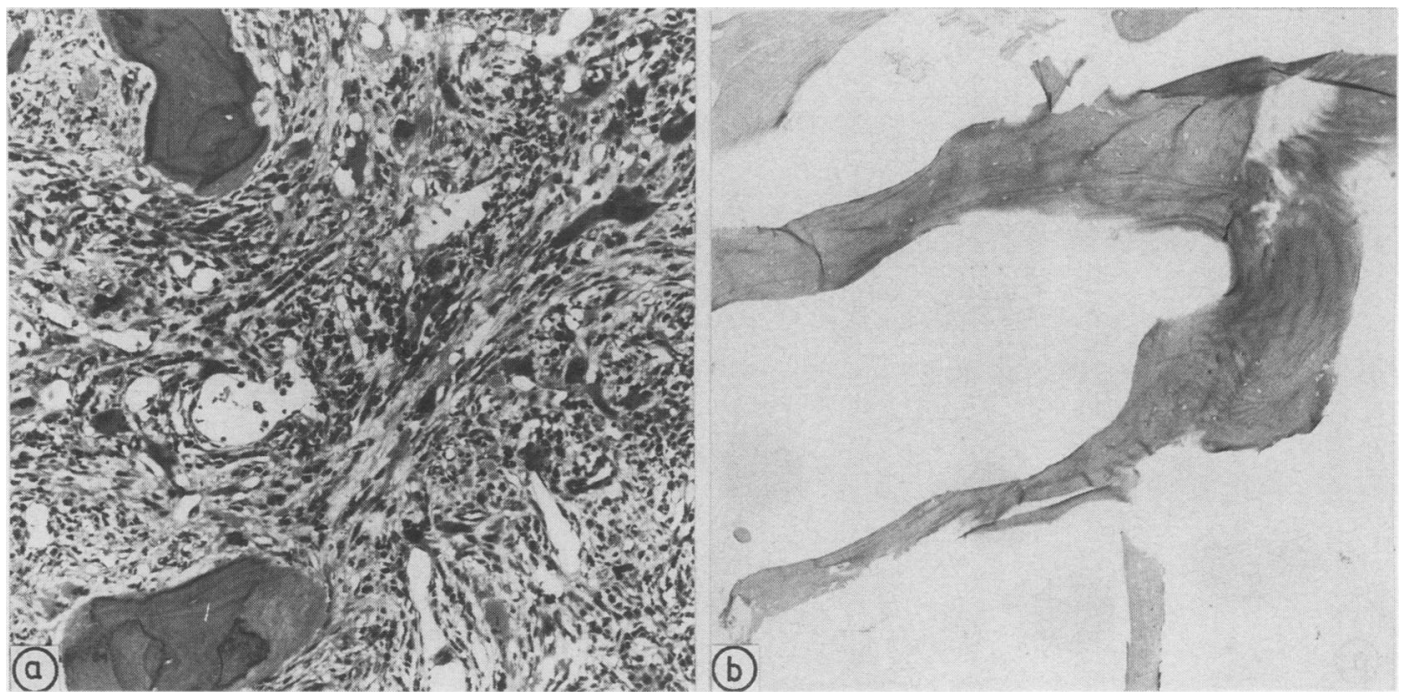

Fig 1 (a) Histological sections of bone marrow from a case of primary myelofibrosis in acute transformation.

(Haematoxylin and eosin.) (b) Same marrow after four hours of collagenase digestion (Haematoxylin and eosin.)

(fig 1), but adequate cell numbers were extracted from all marrows by two hours. The average cell yield for the normal marrow cases was $0.77 \times 10^{6}$ cells $/ \mathrm{mm}$ trephine biopsy specimen (range 0.31-1.79 $\times 10^{6}$ cells $/ \mathrm{mm}$ ). The average cell yield of the diagnostic group was $1.57 \times 10^{6}$ cells $/ \mathrm{mm}$ trephine biopsy specimen (range 0.46-8.78 $\times 10^{6}$ ) for those which gave adequate taps (24 cases), and $0.99 \times 10^{6}$ cells $/ \mathrm{mm}$ trephine biopsy specimen (range $0.42-2.17 \times 10^{6}$ ) for the dry taps (nine cases).

Overnight digestion of aspirate marrow suspensions from the normal group did not result in a significant loss of cells. Average cell recovery was $93 \%$ (range 69-103\%).

\section{CELL MORPHOLOGY AND CYTOCHEMISTRY}

Differential counts on cytocentrifuge preparations of marrows digested with collagenase were very similar to the counts on aspirated marrow smears. Megakaryocytes were seen in cytospins of five of the six normal marrow cores digested.

The cell state of the cytospins stained with MayGrünwald-Giemsa was assessed on morphological grounds as good in 20 of $39(51 \%)$, moderate in eight $(21 \%)$, and poor in $11(28 \%)$. By comparison, the results for the marrow aspirate smears were good in 24 of $30(80 \%)$, moderate in three $(10 \%)$, and poor in three $(10 \%)$ and trephine marrow core roll imprints were good in one of $10(10 \%)$, moderate in one $(10 \%)$, and poor in eight $(80 \%)$. A correct diagnosis could be made on $60 \%$ of the cytospins compared with $70 \%$ of the aspirated marrow smears and $20 \%$ of the roll imprints when each preparation was assessed in isolation (table 1).

Myeloperoxidase, napthyl acetate esterase, napthyl butyrate esterase, periodic acid Schiff, acid phosphatase and iron stains on the digested marrow were positive for the appropriate marrow cells. The reaction strength and staining pattern was variably changed from that of identically stained marrow aspirate smears. Tartrate resistant acid phosphatase (TRAP) staining was positive with a typical strong granular cytoplasmic pattern in both cases of hairy cell leukaemia (fig 2a). Iron staining was seen within marrow macrophages and correlated with reticuloendothelial iron staining seen in the marrow fragments of the aspirated marrow smears.

\section{PHENOTYPING AND DNA ANALYSIS}

On five occasions the epitopes listed in the methods were examined on either normal peripheral blood, mechanically dispersed spleen, or bone marrow samples before and after two hours of digestion. In all cases there was no difference in the number of positive cells nor did the fluorescence intensity differ significantly from the undigested sample. After overnight digestion, however, autofluorescence increased in some but not all samples for both lymphoid and myelogenous lineages to the extent that interpretation was difficult. Examples of phenotypic profiles of collagenase digested marrow and marrow aspirate are given (table 2). Corresponding morphology of digested cells is shown (figs $2 a-2 d$ ).

DNA analysis after digestion at both two hours and 


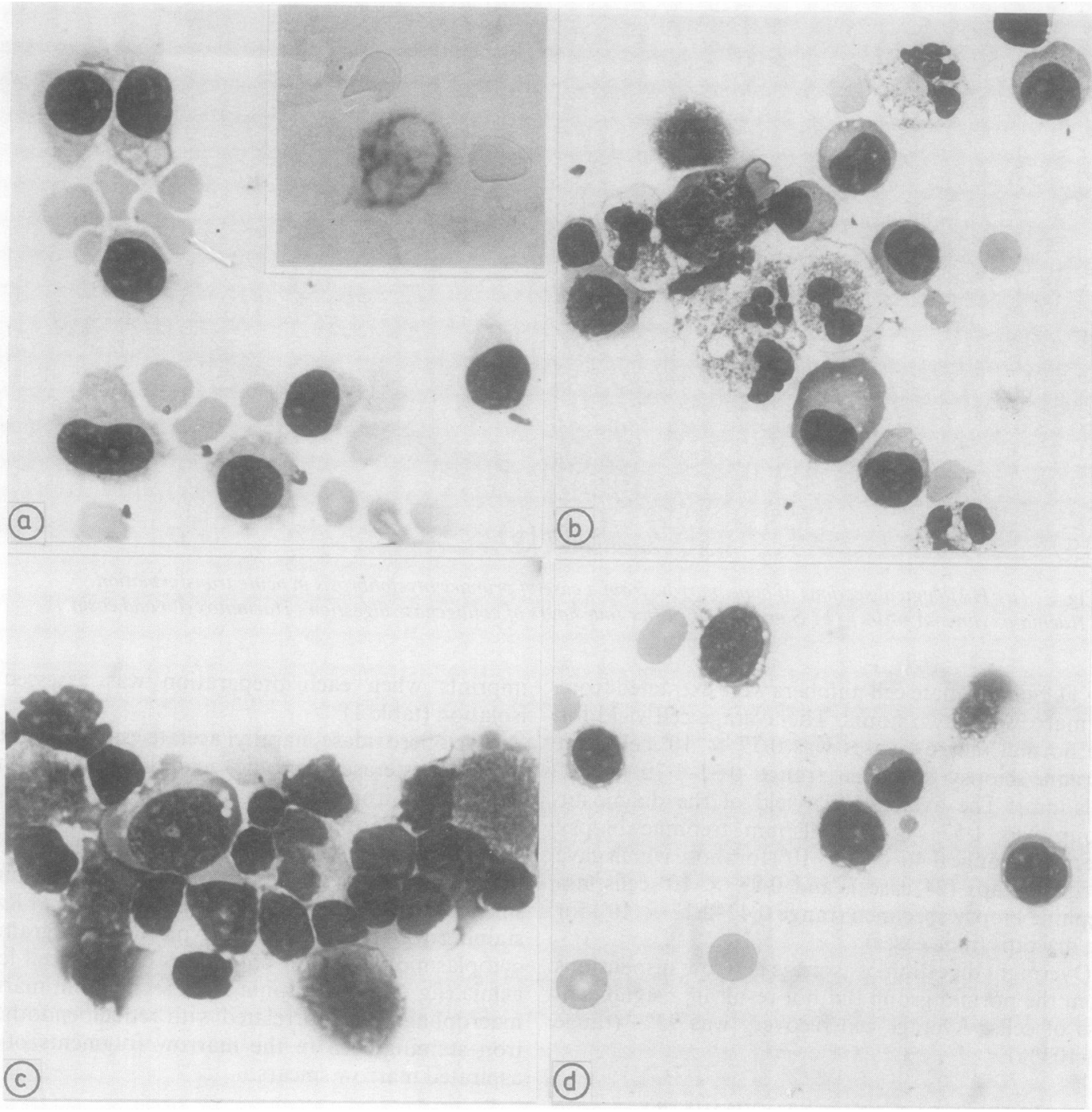

Fig 2 Cytocentrifuge preparations of collagenase digested marrow from the cases shown in table 2. (a) Case 1: hairy cell leukaemia. Cell state assessed as good. (May-Grünwald-Giemsa). Inset. TRAP stain showing typical granular cỳtoplasmic positivity. (b) Case 2: malignant lymphoma, lymphoplasmacytic. Cell state assessed as good.

(May-Grünwald-Giemsa). (c) Case 3: malignant lymphoma, centroblastic-centrocytic. Cell state assessed as poor.

(May-Grünwald-Giemsa). (d) Case 4: malignant lymphoma, lymphocytic. Cell state assessed as moderate.

(May-Grünwald-Giemsa).

overnight was unaffected. The fluorescence intensity and coefficient of variation was essentially unchanged.

\section{KAR YOTYPING}

Three selected trephine digestions were also cultured for cytogenetic analysis. One normal biopsy specimen showed a normal karyotype, a case of chronic myeloid leukaemia showed a single Philadelphia chromosome, and a case of acute lymphoblastic leukaemia, which had a dry tap, showed a deletion of the short arm of chromosome 7.

\section{Discussion}

Collagenase has been used to dissociate cells from soft tissue tumours, ${ }^{3}$ bone marrow in both animal models ${ }^{4}$ and in $\operatorname{man}^{5}$ for bone marrow culture, and as a pretreatment of marrow aspirate in flow cytometry. ${ }^{6}$ 
Table 2 Phenotypic profiles using bone marrow aspirate collagenase digested trephine bone marrow and lymph node preparations in four cases (Numbers are percentages of labelled cells)

\begin{tabular}{|c|c|c|c|c|c|c|c|c|c|c|}
\hline \multirow[b]{2}{*}{ Patients } & \multirow[b]{2}{*}{ Specimen } & \multicolumn{8}{|c|}{ Cell markers } & \multirow[b]{2}{*}{ Diagnosis } \\
\hline & & $I a$ & $\begin{array}{l}J 5 \\
C D 10\end{array}$ & $\begin{array}{l}B 1 \\
C D 20\end{array}$ & $\begin{array}{l}B 4 \\
C D 19\end{array}$ & $F M C 7$ & $\begin{array}{l}T 3 \\
C D 3\end{array}$ & SmIg & IcIg & \\
\hline $\begin{array}{l}1 \text { Female } \\
58 \text { years } \\
2 \text { Female } \\
70 \text { years } \\
3 \text { Male } \\
40 \text { years } \\
4 \text { Female } \\
52 \text { years }\end{array}$ & $\begin{array}{l}\text { Bone marrow aspirate } \\
\text { Collagenase digestion } \\
\text { Bone marrow aspirate } \\
\text { Collagenase digestion } \\
\text { Bone marrow aspirate } \\
\text { Lymph node } \\
\text { Collagenase digestion } \\
\text { Bone marrow aspirate } \\
\text { Collagenase digestion }\end{array}$ & $\begin{array}{l}\text { Not done } \\
85 \\
\text { Dry tap } \\
\text { Not done } \\
\text { Dry tap } \\
88 \\
90 \\
\text { Dry tap } \\
72\end{array}$ & $\begin{array}{l}0 \\
0 \\
\text { Dry tap } \\
\text { Not done } \\
\text { Dry tap } \\
75 \\
80 \\
\text { Dry tap } \\
0\end{array}$ & $\begin{array}{l}26 \\
92 \\
\text { Dry tap } \\
\text { Not done } \\
\text { Dry tap } \\
81 \\
88 \\
\text { Dry tap } \\
60\end{array}$ & $\begin{array}{l}22 \\
90 \\
\text { Dry tap } \\
\text { Not done } \\
\text { Dry tap } \\
70 \\
86 \\
\text { Dry tap } \\
58\end{array}$ & $\begin{array}{l}20 \\
85 \\
\text { Dry tap } \\
\text { Not done } \\
\text { Dry tap } \\
53 \\
\text { Not done } \\
\text { Dry tap } \\
5\end{array}$ & $\begin{array}{l}70 \\
8 \\
\text { Dry tap } \\
\text { Not done } \\
\text { Dry tap } \\
25 \\
5 \\
\text { Dry tap } \\
41\end{array}$ & $\begin{array}{l}25 \mathrm{IgG} \kappa \\
90 \mathrm{IgG} \kappa \\
\text { Dry tap } \\
\text { Not done } \\
\text { Dry tap } \\
75 \mathrm{IgG} \kappa \\
85 \mathrm{IgG} \kappa \\
\text { Dry tap } \\
63 \mathrm{Im} \kappa\end{array}$ & $\begin{array}{l}\text { Not done } \\
\text { Not done } \\
\text { Dry tap } \\
75 \text { IgAd } \\
\text { Dry tap } \\
\text { Not done } \\
\text { Not done } \\
\text { Dry tap } \\
\text { Not done }\end{array}$ & $\begin{array}{l}\text { Hairy cell } \\
\text { leukaemia } \\
\text { Malignant lymphoma, } \\
\text { lymphoplasmacytic } \\
\text { Malignant lymphoma, } \\
\text { centrocytic/centroblastic } \\
\text { Malignant lymphoma, } \\
\text { lymphocytic }\end{array}$ \\
\hline
\end{tabular}

These studies confirm the viability of marrow and tumour cells after exposure to collagenase. The use of collagenase digestion of bone marrow biopsy specimens as a routine diagnostic tool has been reported once $^{7}$ but the study was confined only to morphological assessment.

Our study found that diagnostically useful numbers of cells could be extracted from all marrows, although prolonged digestion was beneficial in some cases with marrow fibrosis. Average cell yield for normal aspirates was $0.77 \times 10^{6}$ cells $/ \mathrm{mm}$ of marrow core which allows 15 epitopes to be analysed using standard flow cytometry methods on a $20 \mathrm{~mm}$ marrow core. Cytocentrifuge preparation using only $10^{5}$ to $2 \times 10^{5}$ cells each for cell morphology and cytochemical analysis can be done without seriously depleting cell numbers for phenotypic analysis. Immunoenzymatic phenotyping techniques can be used on cytospins, ${ }^{8}$ and our preliminary studies have shown that this can be used as a more conservative method on cytospins of digested cells.

Morphological assessment of cytospins of digested marrow gave similar results compared with standard marrow aspirate smears and were most suited to diagnoses dependent on the identification of a discrete abnormal cell population within the marrow. Diagnoses dependent on identifying subtle changes in cell morphology (such as myelodyplasias) may be less reliable because of artefact in the cytospins. Typical artifact seen was nuclear clefting, mechanical distortion, cell debris and degenerative changes in the maturing granulocytic cells.

The results of the phenotyping studies confirmed the persistence of a wide range of useful cell markers after exposure to digestion. The procedure may have advantages compared with aspirated marrow samples because of lack of blood dilution, good cell numbers, and the averaging of irregularly distributed marrow cells achieved by this technique, particularly when marrow pathology is focal. Case 1 in table 2 shows the avoidance of blood dilution by this technique. Preliminary agar marrow culture studies have shown that the clonogenicity of cells extracted from trephine biopsy specimens is maintained.

The method presented is a relatively simple, rapid, and inexpensive means of making cell suspensions from bone marrow biopsy specimens which may be used for cell morphology, cytochemistry, phenotypic analyses, cytogenetic analysis and agar bone marrow culture studies in cases of dry taps.

Our thanks to Dr Nicole Martin, who carried out the cytogenetic analyses, to Dr David DeLeacy for his help in initiating these studies, Jonaelle Teasdale for technical assistance, Gregory Bryson for assistance with flow cytometry and Brenda Walsh for preparation of the manuscript.

\section{References}

1 Dancey JT, Deubelbeiss KA, Harker LA. Section preparation of human marrow for light microscopy. J Clin Pathol 1976;29: 704-10.

2 Wood GS, Warnke RA. The immunological phenotyping of bone marrow biopsies and aspirates: frozen section techniques. Blood 1982;59:913-22.

3 Ablett GA, Smith PJ, Sheridan JW, Lihou MG. Limitations of the agar colony forming assay for the assessment of paediatric tumours. Br J Cancer 1984;50:541-4.

4 Crocker PR, Gordon S. Isolation and characterisation of resident stromal macrophages and haemopoietic cell clusters from mouse bone marrow. Exp Med 1985;162:993-1014.

5 Hotta T, Utsumi M, Katach T, Maeda H, Yamao H, Yamada H. Granulocytic and stromal progenitors in the bone marrow of patients with primary myelofibrosis. Scand J Haematol 1985; 34:251-5.

6 Zeile G. Intracytoplasmic immunofluorescence in multiple myeloma. Cytometry 1980;1:37-41.

7 Mononen I, Jansson SE. A rapid procedure by collagenase treatment and cytocentrifugation, for the cytological evaluation of bone marrow biopsy specimens. Clin Lab Haematol 1986;8: $149-54$.

8 Li C, Witzig TE, Phyliky RL, Ziesmer SC, Lung TY. Diagnosis of B-cell non-Hodgkin's lymphoma of the central nervous system by immunocytochemical analysis of cerebrospinal fluid lymphocytes. Cancer 1986;57:737-44.

Requests for reprints to: Dr C J Ades, Pathology Registrar, Royal Brisbane Hospital, Brisbane, Australia. 